\title{
Determinants of mental health status using depression anxiety stress scales during the COVID-19 pandemic: a systematic review
}

\author{
Riska Nabila ${ }^{1}$, Rizma Adlia Syakurah ${ }^{2}$, Rosyila $^{1}$ \\ ${ }^{1}$ Medical Profession Program, Faculty of Medicine, Sriwijaya University, Palembang, Indonesia \\ ${ }^{2}$ Department of Public Health Sciences, Public Health Faculty, Sriwijaya University, Palembang, Indonesia
}

\begin{tabular}{l} 
Article Info \\
\hline Article history: \\
Received Mar 30, 2021 \\
Revised Nov 20, 2021 \\
Accepted Dec 1, 2021 \\
\hline
\end{tabular}

\section{Keywords:}

Anxiety

COVID-19

DASS

Depression

Mental health

Stress

\begin{abstract}
Coronavirus disease 2019 (COVID-19) is not only being a public physical health emergency, but also affecting global mental health, as evidenced by worldwide panic purchases, independent quarantine, and social distancing. Therefore, it is important to concern how a pandemic might affect one's mental state. The aim of this review was to determine mental health status in the community during COVID-19 pandemic using the depression anxiety stress scales (DASS) self-assessment. A comprehensive and systematic literature search published from January-May 2020 through electronic databases Pubmed, ScienceDirect, and Google Scholar was conducted based on guidelines from Preferred Reporting Items for Systematic Reviews and Meta-Analysis (PRISMA). This study used a self-report tool DASS to assess depression, anxiety, and stress. Seven studies with a total of 15.020 participants that were published in 2020 were included in the analysis. The characteristics that were chosen to determine the mental health status (depression, anxiety, and stress) were age, sex, level of education, and marital status. Findings from this review showed that sociodemographic characteristics (age, sex, marital status, education level) contributed to mental health status (depression, anxiety, and stress).
\end{abstract}

This is an open access article under the $\underline{C C B Y-S A}$ license.

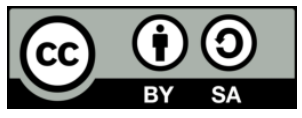

\section{Corresponding Author:}

Rizma Adlia Syakurah Public Health Faculty, Sriwijaya University, Indonesia J1. Raya Palembang-Prabumulih KM. 32 Indralaya, Ogan Ilir, Sumatera Selatan 30662, Indonesia Email: rizma.syakurah@gmail.com

\section{INTRODUCTION}

The coronavirus disease 2019 (COVID-19) infection since first started in China, in December 2019, have been affecting countries all across the world. In March 2020, the World Health Organization (WHO) declared The COVID-19 infection as a global pandemic. During a crisis such as the COVID-19 pandemic, it is important to concern how a pandemic might affect one's mental state. Various things happened such as many rumors circulating about COVID-19, information about the high mortality rate, health programs that limited one's freedom during a pandemic, financial disruption, and conflicts that occurred due to the COVID19 incident can affect one's emotional state and increase the risk of mental disorders [1]. COVID-19 pandemic also has both direct and indirect impacts on the mental health of the community, including fear of falling ill and dying, not wanting to come to health care facilities for fear of contracting while being treated, losing livelihoods, alienation from the community/quarantine because of being linked-relate with the disease, and others. The vulnerable groups affected by mental and psychological health due to the COVID-19 pandemic include people who have direct or indirect contact with the COVID-19 virus, people at high risk of 
contracting (elderly, immunocompromised, and people with preexisting medical illnesses, people who are prone to psychological stressors or people with pre-existing mental disorders), health workers, and people who follow COVID-19 news through various media [1], [2].

Mental health and physical health operate simultaneously to enhance sustainable life. It is proven by the definition of health proposed by the WHO that defines "health as a state of complete physical, mental and social well-being and not merely the absence of disease or infirmity" [3]. Stable mental health provides the ability of individuals to execute their potential, work productively, contribute to the community, and most importantly overcome the pressures of normal life [4]. Each mental disorder can have different symptoms. Symptoms that can arise are feeling excessive anxiety, fear, and sadness. In children, the symptoms might be in the form of changes in learning abilities, being hyperactive, unable to sleep, and irritable [5]. The quarantine can also affect mental health. People who have been quarantined may have a high prevalence of psychological symptoms, such as depression, emotional disturbances, low mood, irritability, stress, insomnia, and post-traumatic stress symptoms [1], [6].

According to research, it is estimated that one in four people subconsciously suffers a mental disorder in their lifetime. It is also strengthened through research by the WHO South-East Asia Region (WHO SEARO) which states that the most depressive cases are in India $(56,675,969$ cases or $4.5 \%$ of the total population) and the lowest in the Maldives (12,739 cases or 3.7\% of the population). As for Indonesia, the estimation is $3.7 \%$ of the population [7]. Therefore disruption of mental health is a major problem without underestimation.

The COVID-19 pandemic that is concurrent with the issue of national regulations which require people to keep a physical distance between each other, going-outside bans, until the closure of the learning area for a while, may affect the physical and mental health of the people. This condition affects the nature of humankind for being social creatures who need to interact directly with others. Another factor of stress comes from the pandemic uncertainty and denouement of its time [8], [9]. WHO classifies causative factors of jeopardized mental health that determine from social, psychological and biological, economic and environmental factors, and interactions, related to behavior. Learning from various affected sectors throughout this pandemic, it is necessary to analyze further the correlation between pandemic and mental health or psychological issue which is a substantial aspect to achieve overall health [10].

Knowledge about mental health and how to prevent them need to be understood and implemented by society to create a healthy society with a good quality of life. Therefore, this systematic review is intended to determine mental health status in the community during the COVID-19 pandemic using the Depression Anxiety Stress Scales (DASS) self-assessment.

\section{METHOD}

\subsection{Search strategy and selection criteria}

This systematic review was conducted based on guidelines from PRISMA (Preferred Reporting Items for Systematic Reviews and Meta-Analysis). This study identified the determinants of mental health status in the community during COVID-19 pandemic using the DASS self-assessment. We performed a comprehensive and systematic literature search published from January-May 2020 through electronic databases Pubmed, ScienceDirect, and Google Scholar with the keyword ("COVID-19" OR "SARS-CoV-2" OR "2019 Novel Coronavirus") AND "mental health" AND "anxiety" AND "stress" AND "depressed" AND "DASS".

We restricted the papers to the full English text and open access (free of charge). Studies that conducted on people who were sick and did not use DASS measurement tools, published before 2020, and editorial articles were excluded as shown in Figure 1.

\subsection{Data extraction and quality assessment}

Potentially relevant studies were first identified by reviewing the titles and abstracts and duplicate studies in various databases were removed. After the screening process, the complete text of the remaining studies was assessed to include the studies within the review. The studies chosen were analyzed by the authors for data extraction, and the findings were discussed with the group. The data extraction table then used to extract the characteristics of each study and the main findings, which include the author, year of publication, country, study design, sample size, age range, sex, level of education, marital status, and major findings. 


\section{RESULTS AND DISCUSSION}

There were 67 studies identified through searching various databases, of which 34 were excluded after screening for duplication, title, and abstract, leaving 33 potentially relevant studies to be retrieved for full-text assessment. Among the 33 remaining studies, 26 were excluded. The authors include seven studies that were found to match the inclusion criteria for the systematic review as presented in Figure 1.

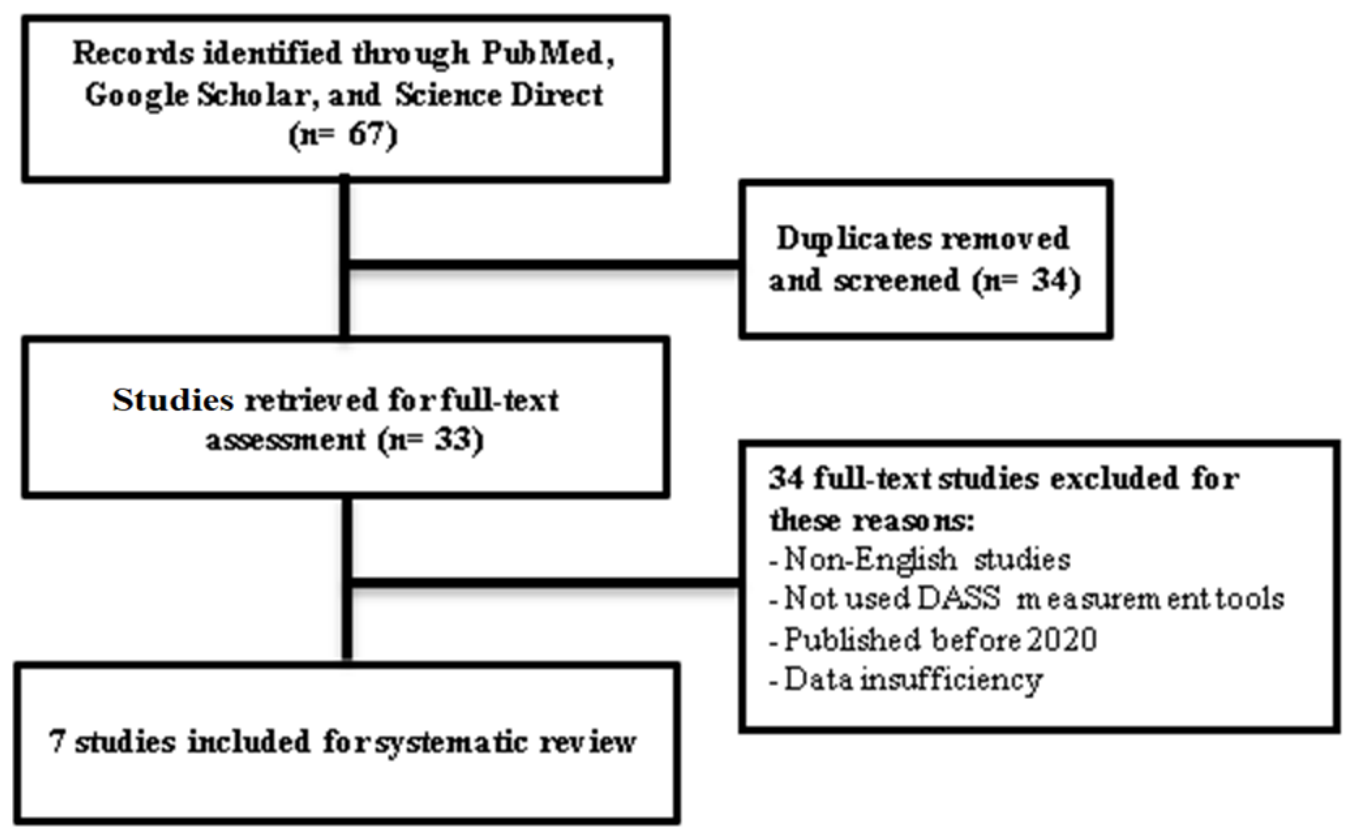

Figure 1. Flow diagram of the study selection process

\subsection{Characteristics of included studies}

After the study selection process, seven studies with a total of 15.020 participants that were published in 2020 were included in the analysis. These studies were conducted in Iraqi Kurdistan, China, Italia, Spain, and India. The characteristics chosen from the studies are age, sex, level of education, and marital status. The summary of the characteristics of each study is provided in Table 1.

Table 1. Characteristics of studies

\begin{tabular}{|c|c|c|c|c|c|c|c|c|}
\hline No & Study & Country & Design & $\begin{array}{l}\text { Sample } \\
\text { size (n) }\end{array}$ & $\begin{array}{l}\text { Age range in } \\
\text { years }(\%)\end{array}$ & $\operatorname{Sex}(\%)$ & $\begin{array}{c}\text { Level of } \\
\text { education } \\
(\%)\end{array}$ & $\begin{array}{c}\text { Marital } \\
\text { status (\%) }\end{array}$ \\
\hline 1 & [11] & $\begin{array}{c}\text { Iraqi } \\
\text { Kurdistan }\end{array}$ & $\begin{array}{c}\text { Quantitative } \\
\text { survey }\end{array}$ & 548 & $18-25(26.8 \%)$ & $\begin{array}{c}\text { Female } \\
(50.4 \%) \\
\text { Male }(49.6 \%)\end{array}$ & $\begin{array}{l}\text { College } \\
(70.4 \%)\end{array}$ & $\begin{array}{l}\text { Married } \\
(75.5 \%)\end{array}$ \\
\hline 2 & [8] & China & $\begin{array}{c}\text { Cross } \\
\text { sectional }\end{array}$ & 1210 & $21-30(53.1 \%)$ & $\begin{array}{c}\text { Female } \\
(67.3 \%) \\
\text { Male }(32.7 \%)\end{array}$ & $\begin{array}{c}\text { Bachelor } \\
(66.5 \%)\end{array}$ & $\begin{array}{l}\text { Married } \\
(76.4 \%)\end{array}$ \\
\hline 3 & [12] & Italia & $\begin{array}{l}\text { Cross- } \\
\text { sectional }\end{array}$ & 2766 & $\begin{array}{l}32.94(13.2 ; \\
\text { range } 18-90 \\
\text { years })\end{array}$ & $\begin{array}{c}\text { Female } \\
(71.7 \%) \\
\text { Male }(28.3 \%)\end{array}$ & $\begin{array}{l}\text { High } \\
\text { school } \\
(43.2 \%)\end{array}$ & $\begin{array}{c}\text { Unmarried } \\
(67.4 \%)\end{array}$ \\
\hline 4 & [13] & China & $\begin{array}{c}\text { Cross } \\
\text { sectional }\end{array}$ & 4872 & $21-30(47.9 \%)$ & $\begin{array}{c}\text { Female } \\
(67.7 \%) \\
\text { Male }(32.3 \%)\end{array}$ & $\begin{array}{l}\text { College } \\
(62.2 \%)\end{array}$ & $\begin{array}{l}\text { Married } \\
(54.0 \%)\end{array}$ \\
\hline 5 & [14] & China & $\begin{array}{c}\text { Cross } \\
\text { sectional }\end{array}$ & 1074 & $\begin{array}{c}14 \text { years to } 68 \\
\text { years }(M=33.54 \\
\text { years, } S D=11.13 \\
\text { years })\end{array}$ & $\begin{array}{c}\text { Female } \\
(46.8 \%) \\
\text { Male }(53.2 \%)\end{array}$ & $\begin{array}{l}\text { High } \\
\text { school } \\
(27.7 \%)\end{array}$ & N/A \\
\hline 6 & [15] & Spain & $\begin{array}{c}\text { Cross } \\
\text { sectional }\end{array}$ & 3550 & $18-25(52.1 \%)$ & $\begin{array}{c}\text { Female } \\
(64.9 \%) \\
\text { Male }(35.1 \%)\end{array}$ & N/A & $\begin{array}{l}\text { Single } \\
(66.0 \%)\end{array}$ \\
\hline 7 & [16] & India & $\begin{array}{c}\text { Cross- } \\
\text { sectional }\end{array}$ & 1000 & $21-25(42 \%)$ & $\begin{array}{c}\text { Female }(62 \%) \\
\text { Male }(38 \%)\end{array}$ & N/A & N/A \\
\hline
\end{tabular}

Int J Public Health Sci, Vol. 11, No. 1, March 2022: 240-247 


\subsection{Mental health status (anxiety) on sociodemographic characteristics}

Of the seven journals reviewed, a study conducted by Wang et al. [8] mentioned a significant relationship between age, sex, education, and marital status with anxiety during the COVID-19 pandemic. Respondents who experienced anxiety were mostly female with an average age of 21-30 years, married, and undergraduate education as shown in Table 2. The highest prevalence of anxiety cases occurred in Italy followed by Iraq, China, and Spain. As for India, the data was not provided.

Table 2. Mental health status (anxiety) on sociodemographic characteristics

\begin{tabular}{|c|c|c|c|c|c|c|c|c|}
\hline No & Study & Country & $\begin{array}{l}\text { Sample } \\
\text { size (n) }\end{array}$ & $\begin{array}{c}\text { Case } \\
(\%)\end{array}$ & Age $(\mathrm{p}<0.05)$ & $\operatorname{Sex}(p<0.05)$ & $\begin{array}{l}\text { Level of Education } \\
(\mathrm{p}<0.05)\end{array}$ & $\begin{array}{l}\text { Marital status } \\
(\mathrm{p}<0.05)\end{array}$ \\
\hline 1 & [11] & $\begin{array}{c}\text { Iraqi } \\
\text { Kurdistan }\end{array}$ & 548 & $47 \%$ & 0.25 & $\begin{array}{c}\text { Female } \\
0.001\end{array}$ & 0.3 & 0.44 \\
\hline 2 & [8] & China & 1210 & $28.8 \%$ & $\begin{array}{l}21-30 \\
0.004\end{array}$ & $\begin{array}{c}\text { Female } \\
0.005\end{array}$ & $\begin{array}{c}\text { Bachelor } \\
<0.001\end{array}$ & $\begin{array}{c}\text { Married } \\
<0.001\end{array}$ \\
\hline 3 & [12] & Italia & 2766 & $81.3 \%$ & $\begin{array}{c}32.94(13.2) \\
0.001\end{array}$ & $\begin{array}{c}\text { Female } \\
<0.001\end{array}$ & 0.135 & 0.690 \\
\hline 4 & [13] & China & 4872 & $22.6 \%$ & $\begin{array}{c}31-40 \\
\text { years }(\mathrm{OR}=1.63 \text {, } \\
95 \% \mathrm{CI}: 1.06- \\
2.51)\end{array}$ & $\begin{array}{c}\text { Female } \\
\text { (OR=0.49, } \\
95 \% \text { CI: } 0.87- \\
1.12)\end{array}$ & $\begin{array}{c}\text { High school } \\
(\mathrm{OR}=0.88, \\
95 \% \mathrm{CI}: 0.65-1.17)\end{array}$ & $\begin{array}{c}\text { Unmarried (OR } \\
=1.07, \\
95 \% \text { CI:0.91-1.26) }\end{array}$ \\
\hline 5 & [14] & China & 1074 & $29.9 \%$ & $\begin{array}{r}21-30 \\
0.001\end{array}$ & 0.088 & N/A & N/A \\
\hline 6 & [15] & Spain & 3550 & $32.4 \%$ & $\begin{array}{l}18-25 \\
-0.03\end{array}$ & 1.53 & N/A & N/A \\
\hline 7 & [16] & India & 1000 & N/A & $\begin{array}{l}21-25 \\
0.000\end{array}$ & $\begin{array}{c}\text { Female } \\
0.000\end{array}$ & N/A & N/A \\
\hline
\end{tabular}

\subsection{Mental health status (depression) on sociodemographic characteristics}

A study conducted by Wang et al.[8] mentioned a significant relationship between age, sex, education and marital status with depression during the COVID-19 pandemic. The remaining studies showed not all sociodemographic characteristics had a significant relationship between age, sex, education, and marital status with the incidence of depression during the COVID-19 pandemic. Respondents who experienced depression were mostly female with an average age of 21-30 years, married, and undergraduate education as shown Table 3. The highest prevalence of depression cases occurred in Italy followed by China, Iraq, and Spain. As for India, the data was not provided.

Table 3. Mental health status (depression) on sociodemographic characteristics

\begin{tabular}{|c|c|c|c|c|c|c|c|c|}
\hline No & Study & Country & $\begin{array}{l}\text { Sample } \\
\text { size }(n)\end{array}$ & $\begin{array}{c}\text { Case } \\
(\%)\end{array}$ & $\begin{array}{c}\text { Age } \\
(\mathrm{p}<0.05)\end{array}$ & $\operatorname{Sex}(p<0.05)$ & $\begin{array}{l}\text { Level of Education } \\
(p<0.05)\end{array}$ & $\begin{array}{c}\text { Marital status } \\
(\mathrm{p}<0.05)\end{array}$ \\
\hline 1 & [11] & Iraqi Kurdistan & 548 & $45 \%$ & 0.85 & $\begin{array}{c}\text { Female } \\
0.02\end{array}$ & College 0.05 & 0.12 \\
\hline 2 & {$[8]$} & China & 1210 & $16.5 \%$ & $\begin{array}{l}21-30 \\
0.009\end{array}$ & $\begin{array}{c}\text { Female } \\
0.003\end{array}$ & $\begin{array}{c}\text { Bachelor } \\
0.003\end{array}$ & $\begin{array}{c}\text { Married } \\
<0.001\end{array}$ \\
\hline 3 & [12] & Italia & 2766 & $67.3 \%$ & 0.236 & $\begin{array}{l}\text { Female } \\
<0.001\end{array}$ & $\begin{array}{l}\text { High school } \\
<0.001\end{array}$ & 0.860 \\
\hline 4 & {$[13]$} & China & 4872 & $48.3 \%$ & $\begin{array}{c}31-40 \\
\text { years } \\
(\mathrm{OR}=1.63 \\
95 \% \mathrm{CI}: 1.06- \\
2.51)\end{array}$ & $\begin{array}{c}\text { Female } \\
\text { (OR=0.49, } \\
95 \% \mathrm{CI}: 0.87- \\
1.12)\end{array}$ & $\begin{array}{c}\text { High school } \\
\text { (OR=0,88, } \\
\text { 95\%CI:0.65-1.17) }\end{array}$ & $\begin{array}{c}\text { Unmarried } \\
\text { (OR=1.07, } \\
\text { 95\%CI:0.91- } \\
1.26)\end{array}$ \\
\hline 5 & [14] & China & 1074 & $37.1 \%$ & $\begin{array}{l}21-30 \\
0.001\end{array}$ & 0.261 & N/A & N/A \\
\hline 6 & [15] & Spain & 3550 & $44.1 \%$ & $\begin{array}{l}18-25 \\
-0.05\end{array}$ & 1.24 & N/A & N/A \\
\hline 7 & [16] & India & 1000 & N/A & $\begin{array}{l}21-25 \\
0.000 \\
\end{array}$ & $\begin{array}{c}\text { Female } \\
0.002 \\
\end{array}$ & N/A & N/A \\
\hline
\end{tabular}

\subsection{Mental health status (stress) on sociodemographic characteristics}

Wang et al. [8] mentioned a significant relationship between age, sex, education, and marital status with stress during the COVID-19 pandemic. The remaining studies showed not all sociodemographic characteristics had a significant relationship between age, sex, education, and marital status with the incidence of stress during the COVID-19 pandemic. Respondents who experienced stress were mostly female with an average age of 21-30 years, married, and undergraduate education as shown in Table 4 . The highest 
prevalence of stress cases occurred in Italy followed by Spain, Iraq, and China. As for India and several studies [13], [14] from China, the data was not provided.

Table 4. Mental health status (stress) on sociodemographic characteristics

\begin{tabular}{ccccccccc}
\hline No & Study & Country & $\begin{array}{c}\text { Sample } \\
\text { size }(\mathrm{n})\end{array}$ & $\begin{array}{c}\text { Case } \\
(\%)\end{array}$ & $\begin{array}{c}\text { Age } \\
(\mathrm{p}<0.05)\end{array}$ & $\begin{array}{c}\text { Sex } \\
(\mathrm{p}<0.05)\end{array}$ & $\begin{array}{c}\text { Level of education } \\
(\mathrm{p}<0.05)\end{array}$ & $\begin{array}{c}\text { Marital status } \\
(\mathrm{p}<0.05)\end{array}$ \\
\hline 1 & {$[11]$} & $\begin{array}{c}\text { Iraqi } \\
\text { Kurdistan }\end{array}$ & 548 & $18 \%$ & 0.1 & 0.4 & College 0.007 & 0.36 \\
& & & & & & & & \\
2 & {$[8]$} & China & 1210 & $8.1 \%$ & $\begin{array}{c}21-30 \\
0.007\end{array}$ & $\begin{array}{c}\text { Female } \\
0.004\end{array}$ & $\begin{array}{c}\text { Bachelor } \\
<0.001\end{array}$ & $\begin{array}{c}\text { Married } \\
0.001\end{array}$ \\
& & & & & & & & \\
3 & {$[12]$} & Italia & 2766 & $72.8 \%$ & $\begin{array}{c}32.94(13.2) \\
<0.001\end{array}$ & $\begin{array}{c}\text { Female } \\
<0.001\end{array}$ & 0.219 & 0.554 \\
4 & {$[13]$} & China & 4872 & N/A & N/A & N/A & N/A & N/A \\
5 & {$[14]$} & China & 1074 & N/A & N/A & N/A & N/A & N/A \\
6 & {$[15]$} & Spain & 3550 & $37.0 \%$ & $\begin{array}{c}18-25 \\
-0.05\end{array}$ & 1.85 & N/A & N/A \\
7 & {$[16]$} & India & 1000 & N/A & $21-25$ & Female & N/A & N/A \\
\hline
\end{tabular}

From studies reviewed, there is a significant correlation between mental health status and the age group of young adults (21-30 years), similar to research which suggests young people tend to get large amounts of information from social media so that they can easily trigger stress [17]. Age is also a factor identifies as one of the determinants of anxiety, conforming searched by Haynes with his opinion stating young people are prone to stress and anxiety [18]. Manuaba argues that young age is more at risk of anxiety because of mental unreadiness as an adolescent with inadequate experience[18]. According to Indonesian Basic Health Research (RISKESDAS), mental disorders have started from 15 to 24 years old, and increase with age [19]. Furthermore, with the development of technology, it is easier to access news through social media, thus increasing anxiety during the pandemic [20]-[22].

This review showed that the level of anxiety and stress was high in females than males. In sync with the findings of the National Mental Health Survey of India 2016, which suggests that females show a higher level of Anxiety as compared to males, similar result has shown in China and Turki [23], [24]. This could be linked to several biological mechanisms that led to depression and anxiety disorders may be more vulnerable in to women, like a difference in the processing of serotonin between the female brain and the male brain which results in dissimilar manifestations of symptoms [25], [26]. The concept of femininity inherent in women causes women to experience more "internalization" disorders such as depression and anxiety [27], [28]. Female also has responsibility for household tasks and the main caregiver for family, so it could have increased, moreover, due to the temporary closure of schools during the lockdown [29], [30].

Marital status is related to one's own mental well-being, as married means the addition of life partners who share emotional sensitivity, both joy and sorrow, in living together. This result is similar with previous study [31], [32] and reinforced by the research of Kessler and Essex which concluded that married people can handle problems better than unmarried people [33]. Further explained that marriage collided with two individuals who have more endurance in reducing emotions from a problem [34]. The impact of the pandemic on the economic sector has caused some employees to be laid off so that it can affect the family economy, such as financial hardship which can lead to an increase in stress levels [35], [36].

Level of education or educational background is proven to affect one's anxiety level [16]. Educational background is a form of additional knowledge for individuals on the grounds of recent relationships with the COVID-19 pandemic [37]. An educated individual, particularly in the medical field, should be better aware of the outbreak conditions, because health workers must be required to understand the illness. Therefore, higher levels of education have better adaptation responses, with rational thinking and broad understanding of stimulus [38].

The correlation of certain variables in this study shows the similarity with the risk factors proposed by Benjamin and $\mathrm{J}$ Sadock. In theory, it is stated that half of the depressed patients have an average age of 40 years and about $50 \%$ of patients have onset between the ages of 20 and 50 years [38]. This is in accordance with the research conducted by Sarwono and Menslin, regarding the theory that the population who are the most vulnerable to depression is young adults aged 18-29 years [26], [39]-[40]. In this study, respondents were female-dominated. it is similar to the research conducted by a previous study, which shows that female students do experience more depressive symptoms because of hormonal conditions in a woman's body [41], [42]. A higher level of education and marital status of marriage had a significant relationship with the

Int J Public Health Sci, Vol. 11, No. 1, March 2022: 240-247 
respondent's depression levels at the time of the COVID-19 pandemic. This is similar to research conducted by Demak and Suherman [17] which states that depression is a mental problem that involves many factors in regulation. Depression reflects the interaction between knowledge factors, biological factors, age, and stressors in the environment and social [34].

Furthermore, age is also known as a factor that is associated with stress, this is because the older age is considered to have a greater tolerance for stress regardless of the type of stressor that happened in an individual's life. Adults are considered capable of controlling stress compared to children and the elderly [43], [44]. National Mental Health Survey of India, shows that stress is highest in the 40-49 years age group. The possible impact that millennials might be experienced due to the locking that affects their personal and professional relationships and dynamics, can be one of the reasons [43], [45].

Women are more susceptible to stress and pain makes mental disorders more likely to occur [46], [47]. A study by APA 2010, shows that women are more likely to become stressed compared to their male counterparts because women tend to link their stress with money and the economy while men do not link their stress with work. This result not only reflects the negative impact of poor quality interpersonal relationships but also the positive effects of good interpersonal relationships, especially people who live together during confinement. Quality of life has been inversely associated with stress, anxiety, and depression, and social relationships and environmental conditions have been linked to stress [8].

Higher education can lead to stress or even fear because someone receives more new information about COVID-19, symptoms, medications, and prevention. Higher education level have sufficient of knowledge about COVID-19 (81.2\%) [37]. So it could be affect the level of acceptance and understanding of an object or material, including awareness during pandemic [48]. This awareness then triggers to take various preventive actions, which can trigger mental health disorders [49], [50]. It differs from the research by Wang et al. [8], found that a person felt far from stressed when he knew the cure rate of COVID-19 increased every day. Perhaps, this result would be more effective if people knew the treatments to manage COVID-19, so the risk of depression, anxiety, and stress could be avoided even further.

This study has limitations. First, self-rating scales were used to assess anxiety, depression, and stress. As the whole country under lockdown, face to face in-depth interview was unlikely to conduct. Therefore, there are always risks of false judgment or over judgment. Moreover, self-report data are subjected to social desirability bias. Second, the Lacking DASS-21 baseline of pre-pandemic data, accurate pre-post analysis cannot be carried out; therefore, we cannot confirm the increased level of difficulty or whether there is an increase (if validated) related to COVID-19.

\section{CONCLUSION}

In conclusion, this systematic review provides more information about the determinants of mental health status during the COVID-19 pandemic in the community. Other findings from this review showed that sociodemographic characteristics (age, sex, marital status, education level) contributed to mental health status (depression, anxiety, and stress). Findings can be used as a reference to provide accurate and factual health information about COVID-19 and create mental health services so that people can reduce levels of anxiety, stress, and depression. Raising public awareness about depression, anxiety, and stress and coping strategies is important to improve mental health, especially in the state of the pandemic.

\section{REFERENCES}

[1] B. Pfefferbaum and C. S. North, "Mental health and the COVID-19 Pandemic," N. Engl. J. Med., vol. 383, no. 6, pp. 510-512, 2020, doi: https://doi.org/10.1056/NEJMp2008017.

[2] A. Fiorillo and P. Gorwood, "The consequences of the COVID-19 pandemic on mental health and implications for clinical practice," Eur. Psychiatry, vol. 63, no. 1, p. e32, 2020, doi: doi: 10.1192/j.eurpsy.2020.35.

[3] World Health Organization, "Mental Health Action Plan," World Health Organization, Geneva, 2013. https://www.who.int/mental_health/publications/action_plan/en/ (accessed May 05, 2020).

[4] D. A. Rifani and D. R. Rahadi, "Emotional instability and people's moods during the COVID-19 pandemic (In Indonesia: ketidakstabilan emosi dan mood masyarakat dimasa pandemi COVID-19)," J. Manaj. Bisnis, vol. 18, no. 1, pp. 22-34, 2021, doi: 10.38043/jmb.v18i1.2747.

[5] Centers for Disease Control and Preventions, "Helping Children Cope," Centers for Disease Control and Preventions, 2020. https://www.cdc.gov/mentalhealth/stress-coping/help-children-cope/index.html (accessed Jun. 20, 2020).

[6] Centers for Disease Control and Preventions, "Stress and Coping," 2015. https://www.cdc.gov/coronavirus/2019-ncov/daily-lifecoping/stress-coping/index.html (accessed Jun. 20, 2020).

[7] World Health Organization, "Depression and other common mental disorders global health estimates," World Health Organization, 2017. https://www.who.int/mental_health/management/depression/prevalence_global_health_estimates/en/ (accessed Jun. 25, 2020).

[8] C. Wang et al., "Immediate psychological responses and associated factors during the initial stage of the 2019 coronavirus disease (COVID-19) epidemic among the general population in China," Int. J. Environ. Res. Public Health, vol. 17, no. 5, p. 1729, 2020, doi: doi: 10.3390/ijerph17051729.

[9] S. Li, Y. Wang, J. Xue, N. Zhao, and T. Zhu, "The impact of COVID-19 epidemic declaration on psychological consequences: a 
study on active Weibo users," Int. J. Environ. Res. Public Health, vol. 17, no. 6, p. 2032, 2020, doi: 10.3390/ijerph17062032.

[10] D. Ayuningtyas, M. Misnaniarti, and M. Rayhani, "Analysis of the mental health situation in society in Indonesia and strategies for overcoming it (In Indonesia: Analisis situasi kesehatan mental pada masyarakat di Indonesia dan strategi penanggulangannya)," J. Ilmu Kesehat. Masy., vol. 9, no. 1, pp. 1-10, 2018, doi: doi: 10.26553/jikm.2018.9.1.1-10.

[11] N. M. Kamal and N. Othman, "Depression, anxiety, and stress in the time of COVID-19 pndemic in Kurdistan Region, Iraq," Kurdistan J. Appl. Res., no. May, pp. 37-44., 2020, doi: 10.24017/covid.5.

[12] C. Mazza et al., "A nationwide survey of psychological distress among italian people during the covid-19 pandemic: Immediate psychological responses and associated factors," Int. J. Environ. Res. Public Health, vol. 17, no. 9, pp. 1-14, 2020, doi: 10.3390/ijerph17093165.

[13] J. Gao et al., "Mental health problems and social media exposure during COVID-19 outbreak," PLoS One, vol. 15, no. 4, p. e0231924, 2020, doi: 10.1371/journal.pone.0231924.

[14] Z. Ahmed et al., "Epidemic of COVID-19 in China and associated psychological problems," Asian J. Psychiatr., vol. 51, no. january, p. 102092, 2020, doi: 10.1016/j.ajp.2020.102092.QOFH.

[15] P. Odriozola-González, Á. Planchuelo-Gómez, M. J. Irurtia, and R. de Luis-García, "Psychological effects of the COVID-19 outbreak and lockdown among students and workers of a Spanish university," Psychiatry Res., vol. 290, no. August, p. 113108, 2020, doi: doi:10.1016/j.psychres.2020.113108.

[16] S. Kazmi, H. DK, T. S, and S. S, "COVID-19 and lockdown: a study on the impact on mental health (Preprint)," SSRN Electron. J., vol. IX, no. IV, pp. 1477-1489, 2020, doi: 10.2139/ssrn.3577515.

[17] I. P. K. Demak and Suherman, "Relationship between age, gender of students and parents' income with anxiety levels in Undergraduate Students of Medical Education Study Program, Faculty of Medicine, Tadulako University (In Indonesia: Hubungan Umur, Jenis Kelamin Mahasiswa Dan Pendapatan Orang Tua Dengan Tingkat Kecemasan Pada Mahasiswa Pendidikan Sarjana Program Studi Pendidikan Dokter Fkik Universitas Tadulako),” J. Ilm. Kedokt., vol. 3, no. 1, pp. 52-62, 2016.

[18] T. R. Sitohang, Y. S. Rosyad, and Y. A. Rias, "Anxiety factor analysis in western Indonesian society during the COVID-19 pandemic in 2020 (In Indonesia: Analisa faktor kecemasan pada masyarakat indonesia bagian barat selama pandemic COVID-19 Tahun 2020)," J. Endur. Kaji. Ilm. Probl. Kesehat., vol. 6, no. 2, pp. 279-289, 2021, [Online]. Available: http://ejournal.kopertis10.or.id/index.php/endurance.

[19] Y. A. Indrayani and T. Wahudi, Mental health situation in Indonesia. Center for Data and Information of the Indonesian Ministry of Health, Winne Widi. Jakarta: Indonesian Ministry of Health Data and Information Center, 2019 (In Indonesia: Situasi kesehatan jiwa di Indonesia. Pusat Data dan Informasi Kementrian Kesehatan RI, Winne Widi. Jakarta: Pusat Data dan Informasi KEMENKES RI. 2019. https://pusdatin.kemkes.go.id/article/view/20031100001/situasi-kesehatan-jiwa-di-indonesia.html (accessed Jun. 20, 2020)

[20] World Health Organization, "Mental health and psychosocial considerations during the COVID-19 outbreak, 18 March 2020 ," Geneva, 2020. https://apps.who.int/iris/handle/10665/331490?locale-attribute=ar\&locale-= (accessed Jun. 20, 2020).

[21] A. Moghanibashi-Mansourieh, "Assessing the anxiety level of Iranian general population during COVID-19 outbreak," Asian J. Psychiatry, vol. 51, no. june, p. 102076, 2020, doi: 10.1016/j.ajp.2020.102076.

[22] R. A. Syakurah, V. Linardi, and I. Bonita, "COVID-19 infodemic and Indonesian emotional and mental health state," International Journal Public Health Science (IJPHS), vol. 10, no. 4, pp. 927-933, 2021, doi: 10.11591/ijphs.v10i4.20964.

[23] Y. Wang, Y. Di, J. Ye, and W. Wei, "Study on the public psychological states and its related factors during the outbreak of coronavirus disease 2019 (COVID-19) in some regions of China," Psychol. Health Med., vol. 26, no. 1, pp. 13-22, 2021, [Online]. Available: https://doi.org/10.1080/13548506.2020.1746817.

[24] S. Özdin and Ş. Bayrak Özdin, "Levels and predictors of anxiety, depression and health anxiety during COVID-19 pandemic in Turkish society: The importance of gender," Int. J. Soc. Psychiatry, vol. 66, no. 5, pp. 504-511, 2020.

[25] R. Verma, Y. P. S. Balhara, and C. S. Gupta, "Gender differences in stress response: Role of developmental and biological determinants," Ind. Psychiatry J., vol. 20, no. 1, p. 4, 2011, doi: 10.4103/0972-6748.98407.

[26] S. Sarwono, Adolescent psychology (In Indonesia: Psikologi Remaja). Jakarta: Raja Grafindo Persada, 2011.

[27] R. K. Thériault and M. L. Perreault, "Hormonal regulation of circuit function: Sex, systems and depression," Biol. Sex Differ., vol. 10, no. 1, pp. 1-14, 2019, doi: 10.1186/s13293-019-0226-x.

[28] F. Van Droogenbroeck, B. Spruyt, and G. Keppens, "Gender differences in mental health problems among adolescents and the role of social support: Results from the Belgian health interview surveys 2008 and 2013," BMC Psychiatry, vol. 18, no. 1, pp. 19, 2018, doi: 10.1186/s12888-018-1591-4.

[29] C. Wenham, J. Smith, R. Morgan, and Gender and COVID-19 Working Group, "COVID-19: the gendered impacts of the outbreak," Lancet (London, England), vol. 395, no. 10227, pp. 846-848, 2020, doi: 10.1016/S0140-6736(20)30526-2.

[30] S. Sediri et al., "Women's mental health: acute impact of COVID-19 pandemic on domestic violence," Arch. Womens. Ment. Health, vol. 23, no. 6, pp. 749-756, 2020.

[31] H. Yang and J. Ma, "How an epidemic outbreak impacts happiness: Factors that worsen (vs. protect) emotional well-being during the coronavirus pandemic," Psychiatry Res., vol. 289, p. 113045, 2020, doi: 10.1016/j.psychres.2020.113045.

[32] M. Ola and R. Mathur, "Is marriage essential for good physical and mental health of women?," Indian J. Heal. Wellbeing, vol. 7 , no. 3, p. 359, 2016.

[33] X. Qin, S. Wang, and C. R. Hsieh, "The prevalence of depression and depressive symptoms among adults in China: estimation based on a National Household Survey," China Econ. Rev., vol. 51, pp. 271-282, 2018.

[34] Manuaba, Human attitude: theory and its measurement, (In Indonesia: Sikap Manusia: Teori Dan Pengukurannya), 2nd ed. Yogyakarta: Pustaka Belajar, 2000

[35] K. L. Archuleta, J. E. Grable, and S. L. Britt, "Financial and relationship satisfaction as a function of harsh start-up and shared goals and values," J. Financ. Couns. Plan., vol. 24, no. 1, pp. 3-14, 2013.

[36] P. G. Sina, "Household Economy in the Era of the COVID-19 Pandemic (In Indonesia: Ekonomi rumah tangga di era pandemi COVID-19)," J. Manag. Small Mediu. Enterp., vol. 12, no. 2, pp. 239-254, 2020.

[37] V. Linardi, R. A. Syakurah, and J. Moudy, "Demography factors influencing Indonesian general knowledge on COVID-19," International Journal Public Health Science, vol. 10, no. 1, pp. 113-118, 2021, doi: 10.11591/ijphs.v10i1.20515.

[38] N. Putri, J. E. Tyaswati, and A. Santosa, "Relationship between Depression Level and Quality of Life of CKD Patients Undergoing Hemodialysis at the Hospital. Dr. Soebandi Jember (In Indonesia: Hubungan antara Tingkat Depresi dengan Kualitas Hidup Pasien CKD yang Menjalani Hemodialisis di RsD. Dr. Soebandi Jember),”e-Jurnal Pustaka Kesehat., vol. 4, no. 3, pp. 458-465, 2016.

[39] H. Hadianto, "Prevalence and risk factors related to the level of depressive symptoms in students of the medical education study

Int J Public Health Sci, Vol. 11, No. 1, March 2022: 240-247 
program at Tanjungpura University (In Indonesia: Prevalensi dan faktor-faktor risiko yang berhubungan dengan tingkat gejala depresi pada mahasiswa program studi pendidikan dokter fakultas kedokteran Universitas Tanjungpura)," J. Mhs. PSPD FK Univ. Tanjungpura, vol. 1, no. 1, pp. 1-18, 2014.

[40] R. Mojtabai, M. Olfson, and B. Han, "National trends in the prevalence and treatment of depression in adolescents and young adults," Pediatrics, vol. 138, no. 6, p. e20161878, 2016, doi: 10.1542/peds.2016-1878

[41] R. R. Ansori and T. Martiana, "The relationship of individual characteristics factors and working conditions to job stress in dental nurses (In Indonesia: Hubungan faktor karakteristik individu dan kondisi pekerjaan terhadap stres kerja pada perawat gigi)," Indones. J. Public Heal., vol. 12, no. 1, pp. 75-84, 2017, doi: 10.20473/ijph.v12i1.2017.75-84.

[42] D. Natalia and R. A. Syakurah, "Mental health state in medical students during COVID-19 pandemic," J. Educ. Health Promot., vol. 10, no. 1, p. 208, 2021, doi: 10.4103/jehp.jehp 129620.

[43] M. S. Gautham et al., "The National Mental Health Survey of India (2016): Prevalence, socio-demographic correlates and treatment gap of mental morbidity," Int. J. Soc. Psychiatry, vol. 66, no. 4, pp. 361-372, 2020, doi: 10.1177/0020764020907941.

[44] J. Zhou et al., "Prevalence of depression and its correlative factors among female adolescents in China during the coronavirus disease 2019 outbreak.," Global. Health, vol. 16, no. 1, pp. 1-6, 2020.

[45] J. H. Flaskerud, "Stress in the Age of COVID-19," Issues Ment. Health Nurs., vol. 42, no. 1, pp. 99-102, 2020.

[46] W. Gao, S. Ping, and X. Liu, "Gender differences in depression, anxiety, and stress among college students: A longitudinal study from China,” J. Affect. Disord., vol. 263, pp. 292-300, 2020, doi: /10.1016/j.jad.2019.11.121.

[47] J. Caputo and R. W. Simon, "Physical limitation and emotional well-being: Gender and marital status variations," J. Health Soc. Behav., vol. 54, no. 2, pp. 241-257, 2013, doi: doi:10.1177/0022146513484766.

[48] A. Fadhilah, M. Azzuhri, and S. Andarini, "The Effect Of Clarity Of Information And Comfort Of Waiting Room On Satisfaction With Drug Service Through Perception Of Waiting Time," J. Apl. Manaj., vol. 16, no. 2, pp. 205-214, 2018.

[49] B. Masyah, "The COVID-19 Pandemic on Mental Health and Psychosocial (In Indonesia: Pandemi COVID-19 terhadap Kesehatan Mental dan Psikososial)," Mahakan Noursing, vol. 2, no. 8, pp. 353-362, 2020.

[50] M. Ueda, A. Stickley, H. Sueki, and T. Matsubayashi, "Mental health status of the general population during the COVID-19 Pandemic: A cross-sectional national survey in Japan,” MedRxiv, vol. 3, pp. 1-11, 2020.

\section{BIOGRAPHIES OF AUTHORS}

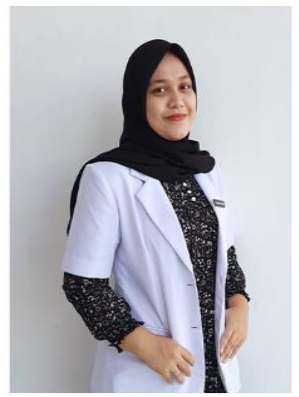

Riska Nabila (D) 8d SC P completed his undergraduate education at the Faculty of Medicine, Sriwijaya University, Palembang. She is currently undergoing an internship doctor program at the Tebing Tinggi Empat Lawang Hospital. During college, she actively served as secretary of the student representative council and a member of FKIA. She interested in doing research related to environmental health. Email: riskanabila60@ gmail.com.

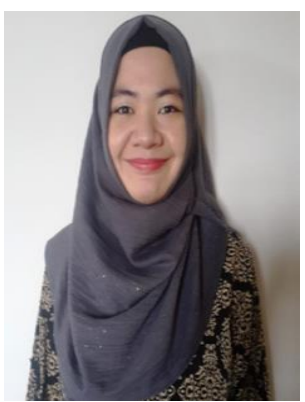

Rizma Adlia Syakurah (iD) SC $\mathrm{P}$ completed her magister degree of Hospital Administration in Universitas Indonesia and doctorate in Medical Education And Public Health in Universitas Gadjah Mada. She is currently teaching in Sriwijaya University as a lecturer. Her research interest includes health management and intervention, health promotion, health communication, medical education, and inter-professional education. She is currently also interested in management and mitigation of COVID-19 through health education and community development. She can be contacted at email: rizma.syakurah@gmail.com.

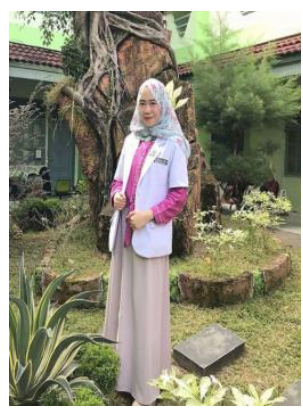

Rosyila (D) SI SC P completed his undergraduate education at the Faculty of Medicine, Sriwijaya University, Palembang. During college, she actively Wilsa Medical Student Health Ambassador. She can be contacted at email: syila_rosyila96@yahoo.com. 